\title{
A STUDY ON INFORMATION SEEKING BEHAVIOUR OF STUDENTS WITH SPECIAL REFERENCE TO ENGINEERING COLLEGES IN
}

\section{VELLORE DISTRICT}

\section{G. SARALA}

Deputy Librarian, Kingston Engineering College, Vellore, Tamil Nadu, India

ABSTRACT
Information seeking behavior is mainly dealing with the way people search for information, identify \& utilize
information. It is a process by which individuals seeking, identifying, selecting, evaluating and analyzing information in
order to change their state of knowledge. The main aim of this study is to examine the information seeking behavior of
Library Users in selected Engineering colleges in Vellore district. This study mainly focuses on frequency of library visits,
purposes of Information seeking, searching tools, various factors influencing the information seeking behavior and the
problems faced by them during the process of information seeking. The questionnaires were randomly distributed among
180 respondents and received 144 respondents, with $80 \%$ of the result.
KEYWORDS: Information Seeking Behaviour, Engineering Colleges \& Library Users

Received: Apr 03, 2017; Accepted: May 02, 2017; Published: May 23, 2017; Paper Id.: IJLSRJUN20175

\section{INTRODUCTION}

\section{Information}

Nowadays, Information is a basic necessity of everyone in the world. Everybody require information for their use. Information is the valuable asset than all other movable and immovable asset. In the contemporary world, all people are not valued for their assets as they rich or poor, because they are valued as information rich and information poor. People those who are identifying and searching information, to access the information successfully and satisfying their needs called as Information rich people. People those who are lacking in their skills to get their required information called as Information poor people.

Information is also viewed as "all knowledge, ideas, facts, data and imaginative works of the mind, which are communicated formally and/or informally in any format" (Chen and Hernon, 1982) 1 .

\section{Information Needs}

Information needs highlight the requirement of users' need. Information need influences the information seeking process that depends on the correctly determined information need. Lack in determining the correct information need will create a puzzled state, which will lead to uselessness in getting the information needed to be satisfied.

Information need implies "a state that arises within a person, suggesting some kind of a gap that requires filling. When applied to the word information, as in information need, what is suggested is a gap that can be filled by something that the needing person calls "information". (Dervin, B. \& Nilan, M. 1986) ${ }^{2}$. 


\section{Information Seeking Behaviour}

The present era is the era of information revolution. Numerous Information on the Web and a huge amount of printed information arranged in different containers and in different locations is all available in the Library. The Information explosion has affected information seeking behavior. Information seeking behavior involves personal reasons for searching information, the kinds of information which are being required, and the ways and sources with which needed information is being required.

Information seeking behavior refers to the way people search for and utilize information. Many times, information seeking behavior involves active information seeking as a result of the information need to complete course assignments, prepare for class notes, prepare the articles for seminars, workshops \& conferences, research papers and update their knowledge. Information Seeking Behavior has been defined differently by different researchers. In this section, the various definitions will be viewed.

Information seeking behavior refers to those activities a person engages in, when identifying his or her own need for information, searching for such information in any way, and using or transferring of information. Information behavior

is the totality of human behavior in relation to the sources and channels of information, including both active and passive information seeking and information use. Thus, it includes face to face and online communication with others as well as the passive reception of information (Wilson, 2000)3.

Information seeking behavior is a broad term and refers to those actions, that an individual takes to articulate, seek, evaluate, select and, finally use the required information for meeting his/ her information needs (Majid and Kassim, $2002) 4$.

\section{REVIEW LITERATURE}

A study examined Information Seeking Behavior in two Law Colleges in Mumbai that the Law students use ITbased library sources and facilities more frequently along with printed sources, and the students of both the colleges face the problem of information overload on the internet and lack of skills to search information Jayadev H. Kadli and Veeresh B. Hanchinal (2015) 5

A study focused on the differences in print media and electronic media, and showed that only a small percentage of the general public prefer to learn by reading Kadli Jayadev and Kumbar B. D (2011) ${ }^{6}$.

A study explored the awareness of researchers about the services offered by the Central Drug Research Institute (CDRI) in Lucknow, India, and determined the purpose and type of information sought by CDRI researchers. Results reveal that most researchers visit the library weekly, generally to collect reading material Raza M. Masoom and others 2010) ${ }^{7}$.

Major findings from this study include, academic information was rated as the predominant information required by the students, while the Internet was rated the most crucial source of most of the academic information required (Padnzamma, S and Others, 2010) ${ }^{8}$

The study discussed the findings of various strategies and procedures adopted by the agricultural scientists in meeting their information requirement. The results show that agricultural scientists had expressed great dependence in meeting their information requirement on their institutional library/information centre. For accessing information, the users 
highly depend on the library collection, followed by the personal collection, a collection of their supervisor and colleagues in order of decreasing priority (Singh K. P. And Satija M. P. 2008) ${ }^{\text {9. }}$

\section{OBJECTIVES}

- To investigate the information needs and Information Seeking Behaviors of Library Users in the selected Engineering College in Vellore.

- To identify the information Channels and sources used by the students.

- To determine the type of information sources used by the students for their need.

- To identify the main barriers Engineering College Users faced in meeting their information needs.

- To measure user satisfaction levels with library resources and services in college library

\section{SCOPE OF THE STUDY}

The present study is limited to Seven Engineering College Libraries in Vellore District, Tamil Nadu, affiliated to Anna University, Chennai. \& approved by AICTE, New Delhi. - Kingston Engineering College (KEC), Ganadipathy Tulsi's Jain Engineering College (GTEC), Global Institute of Technology and Engineering College (GIET), C. Abdul Hakeem College of Engineering \& Technology (CAHCET), Priyadharshini Engineering College (PEC), Ranipettai Engineering College (REC), Adhi Parasakthi Engineering College (APCE).

\section{METHODOLOGY}

This study aims to evaluate the responsiveness of Information seeking behavior of Library Users in the selected Engineering College in Vellore District, Tamil Nadu. Descriptive research design was adopted. All library users constitute the population. Survey method was adopted to gather primary data using a structured questionnaire. A total of 180 questionnaires were distributed among users and 144 filled in questionnaires received. The questionnaire was administrated by the researchers directly to the selected samples. The collected data from the respondents, the data were checked and analyzed according to objectives. The study mainly finds out the User satisfaction levels towards existing library resources and services.

\section{DATA ANALYSIS AND INTERPRETATIONS}

A total of 180 questionnaires have distributed among users and 144 filled in questionnaires were received and the data is given in the Table 1 Thus resulting with response rate of $80 \%$.

Table 1: Response Rate

\begin{tabular}{|l|c|c|}
\hline No. Of Questionnaire & No. of Respondents & Percentage \\
\hline Disturbed & 180 & 100 \\
\hline Received & 144 & 80 \\
\hline
\end{tabular}

Question wise analysis of the data is presented here. Percentages and statistical techniques are used for interpretation of the data. Discussion on the interpretation is extended with possible reasons for the existing situation with regard to various aspects of the study. 


\section{Library Use}

It is generally accepted that the frequency of library visits by the user depends on the nature and Resources Collection, Organization and Maintenance of the Collection and the provision of variety information services that a library provides. In this survey, it is Engineering College the information updating is an essential component to achieve success in the courses. Keeping this in mind, the respondents were asked to state the frequency of visits to the library. The users were asked to indicate the frequency of visits to the library. It is seen (Table 2) that the majority of the users $(56.94 \%)$ visits once in a week, following that $21.53 \%$ visits daily, $16.67 \%$ visits more than once in a month.

Table 2: Frequency of Visits to the Library

\begin{tabular}{|c|c|c|c|c|c|c|c|c|}
\hline \multicolumn{1}{|c|}{ Frequency } & KEC & GTEC & GIET & CAHCET & PEC & REC & APCE & Total \\
\hline Daily & $7(4.86)$ & $4(2.78)$ & $5(3.47)$ & $2(1.39)$ & $4(2.78)$ & $3(2.08)$ & $6(4.17)$ & $\mathbf{3 1}(\mathbf{2 1 . 5 3})$ \\
\hline Once in a week & $16(11.11)$ & $12(8.33)$ & $9(6.25)$ & $19(13.19)$ & $7(4.86)$ & $10(6.94)$ & $9(6.25)$ & $\mathbf{8 2}(\mathbf{5 6 . 9 4})$ \\
\hline Once in a fortnight & $1(0.69)$ & $3(2.08)$ & $1(.69)$ & $1(.69)$ & $0(.00)$ & $1(.69)$ & $0(.00)$ & $\mathbf{7 ( 3 . 4 7 )}$ \\
\hline Once in a Month & $3(2.08)$ & $5(3.47)$ & $5(3.47)$ & $5(3.47)$ & $1(.69)$ & $3(2.08)$ & $2(1.39)$ & $\mathbf{2 4}(\mathbf{1 6 . 6 7})$ \\
\hline Total & $\mathbf{2 7}(\mathbf{1 8 . 7 5})$ & $\mathbf{2 4}(\mathbf{1 6 . 6 7})$ & $\mathbf{2 0}(\mathbf{1 3 . 8 9})$ & $\mathbf{2 7}(\mathbf{1 8 . 7 5})$ & $\mathbf{1 2}(\mathbf{8 . 3 3})$ & $\mathbf{1 7}(\mathbf{1 1 . 8 1})$ & $\mathbf{1 7}(\mathbf{1 1 . 8 1})$ & $\mathbf{1 4 4}(\mathbf{1 0 0 . 0 0})$ \\
\hline
\end{tabular}

(Figures in the Parenthesis indicate percentage)

\section{Types of Materials Frequently Used By the Users}

Table 3 shows that $(80.56 \%)$ most of the users visit to the library for reading textbooks and $46.53 \%$ visit for studying the general books, followed by $41.67 \%$ visit for reference books and finally $22.22 \%$ visit for competitive Examination books.

Table 3: Colleges Vs Types of Materials

\begin{tabular}{|c|c|c|c|c|c|c|c|c|}
\hline $\begin{array}{c}\text { MATERIAL } \\
\text { TYPES }\end{array}$ & KEC & GTEC & GIET & CAHCET & PEC & REC & APCE & Total \\
\hline Textbooks & $25(17.36)$ & $18(12.50)$ & $13(9.03)$ & $22(15.28)$ & $11(7.64)$ & $14(9.72)$ & $13(9.03)$ & $\begin{array}{c}116 \\
(80.56)\end{array}$ \\
\hline Periodicals & 2(1.39) & 2(1.39) & $0(0)$ & $3(2.08)$ & $5(3.47)$ & $2(1.39)$ & $3(2.08)$ & $\begin{array}{c}17 \\
(11.81)\end{array}$ \\
\hline Newspapers & $14(9.72)$ & $12(8.33)$ & $6(4.17)$ & $10(6.94)$ & $3(2.08)$ & $6(4.17)$ & $4(2.78)$ & $\begin{array}{c}55 \\
(38.19) \\
\end{array}$ \\
\hline Reference Books & $12(8.33)$ & $6(4.17)$ & $6(4.17)$ & $15(10.42)$ & $6(4.17)$ & $8(5.56)$ & $7(4.86)$ & $\begin{array}{c}60 \\
(41.67)\end{array}$ \\
\hline General Books & $9(6.25)$ & 14(9.72) & $6(4.17)$ & $15(10.42)$ & $7(4.86)$ & $7(4.86)$ & $9(6.25)$ & $\begin{array}{c}67 \\
(46.53)\end{array}$ \\
\hline $\begin{array}{l}\text { Competitive } \\
\text { Exam Books }\end{array}$ & $8(5.56)$ & $3(2.08)$ & $5(3.47)$ & $9(6.25)$ & $3(2.08)$ & $3(2.08)$ & $1(0.69)$ & $\begin{array}{c}32 \\
(22.22) \\
\end{array}$ \\
\hline
\end{tabular}

\section{Purposes of using the Library}

When the information needs of the users increase, the use of libraries is increasing. Table 4 shows that $59.03 \%$ library users use the library for updating knowledge followed by $54.17 \%$ use library for writing assignments and $43.06 \%$ use the library for preparing their examinations.

Table 4: Purpose of using the Library

\begin{tabular}{|l|l|l|l|l|l|l|l|l|}
\hline \multicolumn{1}{|c|}{ Purpose } & \multicolumn{1}{|c|}{ KEC } & \multicolumn{1}{c|}{ GTEC } & \multicolumn{1}{c|}{ GIET } & \multicolumn{1}{c|}{ CAHCET } & \multicolumn{1}{c|}{ PEC } & \multicolumn{1}{c|}{ REC } & \multicolumn{1}{c|}{ APCE } & \multicolumn{1}{c|}{ Total } \\
\hline For Preparing Examination & $14(9.72)$ & $10(6.94)$ & $6(4.17)$ & $13(9.03)$ & $4(2.78)$ & $6(4.17)$ & $9(6.25)$ & $62(43.06)$ \\
\hline For Updating Knowledge & $14(9.72)$ & $14(9.72)$ & $13(9.03)$ & $19(13.19)$ & $7(4.86)$ & $9(6.25)$ & $9(6.25)$ & $85(59.03)$ \\
\hline For Writing Assignments & $15(10.42)$ & $17(11.81)$ & $7(4.86)$ & $14(9.72)$ & $6(4.17)$ & $11(7.64)$ & $8(5.56)$ & $78(54.17)$ \\
\hline For Writing Papers & $7(4.86)$ & $6(4.17)$ & $6(4.17)$ & $2(1.39)$ & $3(2.08)$ & $6(4.17)$ & $3(2.08)$ & $33(22.92)$ \\
\hline For Entertain-ment & $5(3.47)$ & $2(1.39)$ & $5(3.47)$ & $6(4.17)$ & $0(.00)$ & $3(2.08)$ & $2(1.39)$ & $23(15.97)$ \\
\hline Any Other & $14(9.72)$ & $10(6.94)$ & $5(3.47)$ & $14(9.72)$ & $4(2.78)$ & $8(5.56)$ & $5(3.47)$ & $60(41.67)$ \\
\hline
\end{tabular}


Information Searching Tools Used to Access Documents

Table 5

\begin{tabular}{|l|l|l|l|}
\hline \multirow{2}{*}{\multicolumn{1}{|c|}{ Tools Used }} & \multicolumn{2}{c|}{ No. of User } & \multirow{2}{*}{ Total } \\
\cline { 2 - 3 } & \multicolumn{1}{|c|}{ Yes } & \multicolumn{1}{c|}{ No. } & \\
\hline Library Catalogue & $61(42.36)$ & $83(57.64)$ & $144(100)$ \\
\hline References from the books & $95(65.97)$ & $49(37.03)$ & $144(100)$ \\
\hline References from the periodicals & $26(18.05)$ & $118(81.95)$ & $144(100)$ \\
\hline
\end{tabular}

It is evident from the above Table 5 that the majority $(65.97 \%)$ of respondents used reference from the books to access documents, followed by $42.36 \%$ of respondents used library catalogue to access documents, $18.05 \%$ of the respondents only used references from the periodicals.

\section{Problems Faced By the Users While Seeking Information}

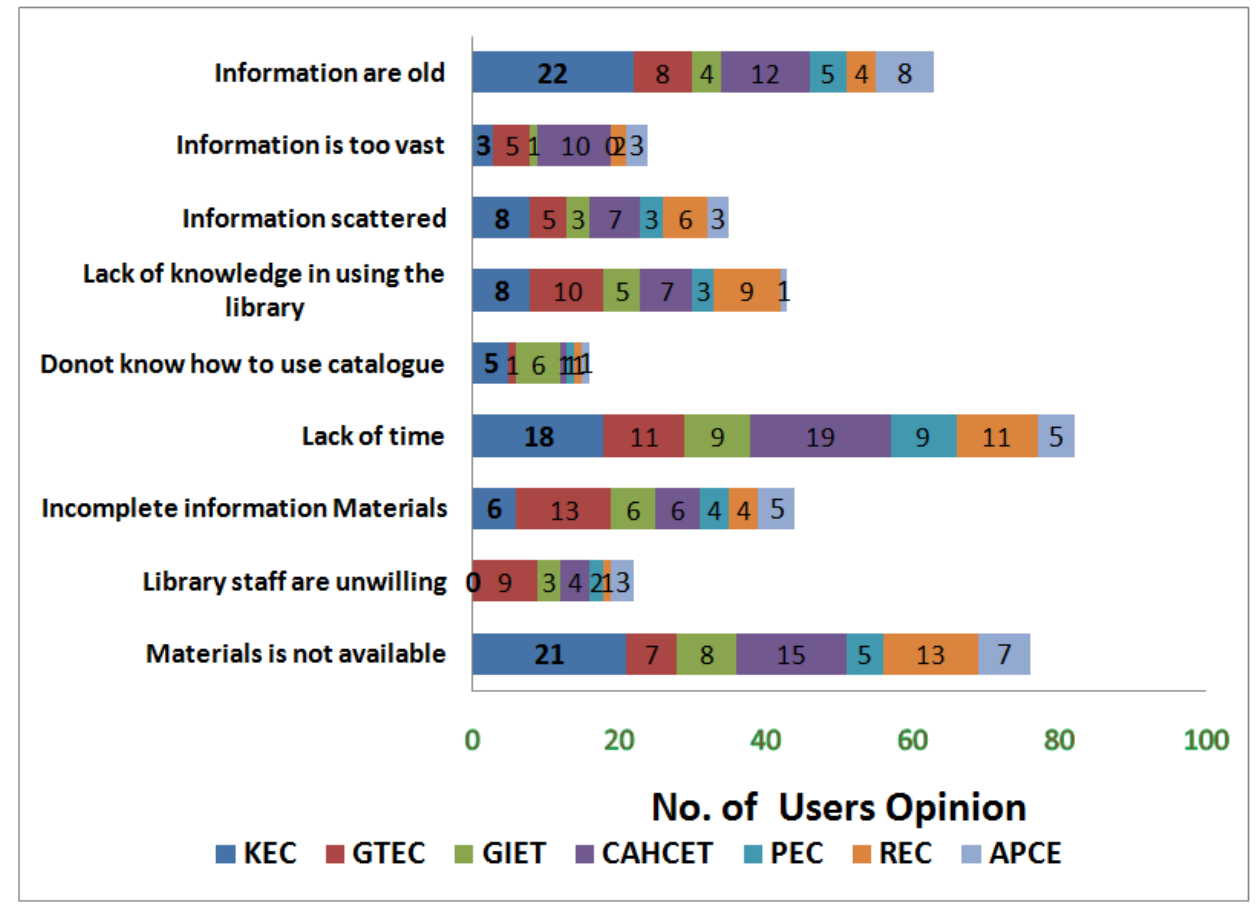

Chart 1: Problems Faced By the Users While Seeking the Information

Generally, students faced the common problems while searching their required information in the library that is not availability of information and lack of time.

The above table 4.1 .10 shows that the majority of students $82(56.94 \%)$ faced lack of time for searching, followed that $76(52.78 \%)$ of them faced unavailability of information for searching, $63(43.75 \%)$ of them faced information materials are old and $44(30.55 \%)$ of them faced incomplete information materials are available while searching the information.

\section{Library Collection and Information Sources}

Chart No. 2 presents the data with regard to level of adequacy of library collection and information sources.

The below figure shows the users' opinion regarding Books, Reference Books, Journals/Periodicals, Newspapers, 
General Magazines, and Competitive Exams Magazines. More than 80 percent of the users have expressed high adequacy of Books and Newspapers and less than 42 percent of users have expressed the inadequacy of competitive exams Magazines, General Magazines, Reference Books and Journals/ Periodicals.

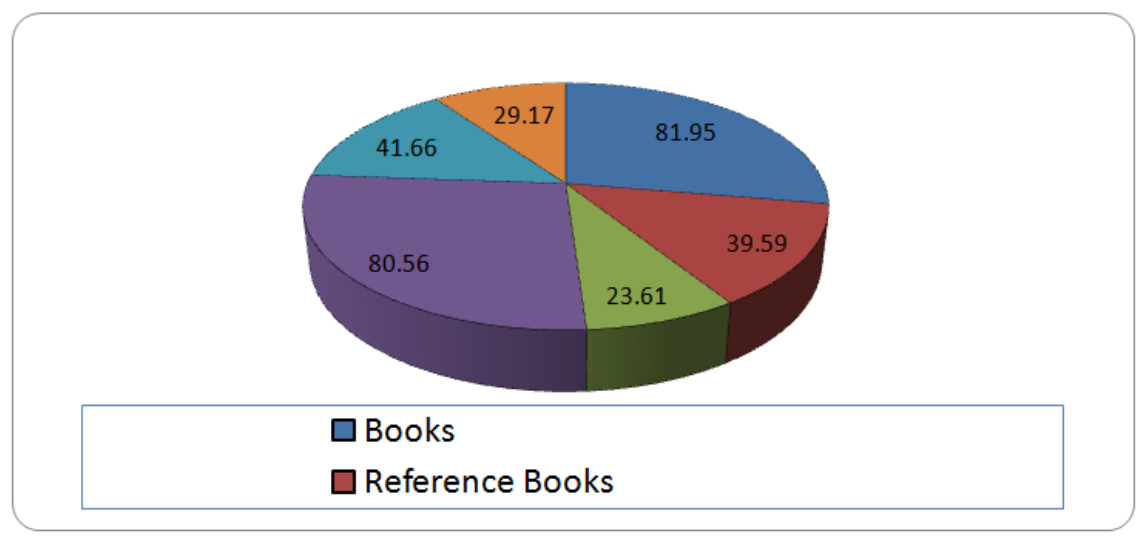

Chart 2: Respondents Opinion about Library Collection

Satisfaction of Library Services

Table 6: Satisfaction of Library Services

\begin{tabular}{|c|c|c|c|c|c|c|c|c|}
\hline Satisfi & KECa & GTECa & GIET $₫$ & CAHCET & $\mathrm{PEC} \alpha$ & RECa & APCEa & Totala \\
\hline YESO & $25(17.36)$ & $23(15.97) \alpha$ & $18(12.50)$ & $26(18.05) \mathfrak{a}$ & $10(6.94)$ & 15(10.41)a & 15.(10.41) & 132( \\
\hline NOd & $2(2.08) 0$ & 1(0.69)ם & $2(1.38) x$ & $1(0.69) 0$ & $2(1.38) x$ & $2(1.38) 0$ & $2(1.38) 0$ & $12(8.33) \not$ \\
\hline Totala & $27(18.75) \mathrm{d}$ & $24(16.67) ם$ & $20(13.89)$ ם & $27(18.75) \mathrm{d}$ & $12(8.33) a$ & 17(11.81) $\mathrm{d}$ & $17(11.81) \mathrm{a}$ & $144(100) \mathrm{a}$ \\
\hline
\end{tabular}

Table 6 shows that $92 \%$ of them were satisfied with the library services and $8 \%$ of them were not satisfied with the library services. Therefore, it can be concluded from the above data that the majority of respondents were satisfied with Library Services.

\section{Library Orientation Programme}

It is evident from the above table that most of the respondents $(90.97 \%)$ indicated that they required library orientation programme to utilize the resources effectively and the remaining $(9.03 \%)$ replied negatively. It reveals that the library orientation program was required by the users.

Table 7: Users' Opinion Regarding Library Orientation Programme

\begin{tabular}{|c|c|c|c|c|c|c|c|c|}
\hline OP & a & Ca & $\Gamma$ & ETa & PECa & RI & AP & \\
\hline Sati & & & & & & 7 & & \\
\hline Not & & & & & & & & \\
\hline Totala & $27(18.75) \mathrm{a}$ & $24(16.67) a$ & 2013.89)a & $27(18.75) a$ & $12(8.33) \mathrm{a}$ & 17(11.81)a & $17(11.81) a$ & 144(100)a \\
\hline
\end{tabular}

\section{Users Opinion about the Library Facilities}

The data collected are presented in the above table 8 more than 75 percent of students were satisfied with the library facilities, and remaining 25 percent students were not satisfied and neither satisfied nor dissatisfied. 
Table 8

\begin{tabular}{|c|c|c|c|c|c|c|c|c|}
\hline \multirow[b]{2}{*}{ Sl. No. } & \multirow[b]{2}{*}{ Facilities } & \multicolumn{2}{|c|}{ Satisfied } & \multicolumn{2}{|c|}{ Dissatisfied } & \multicolumn{2}{|c|}{$\begin{array}{l}\text { Neither satisfied } \\
\text { Nor Dissatisfied }\end{array}$} & \multirow[b]{2}{*}{ TOTAL } \\
\hline & & 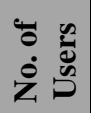 & $\%$ & 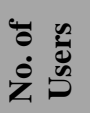 & $\%$ & $\begin{array}{l}\ddot{0} \\
\dot{0} \\
\dot{0} \\
\dot{z}\end{array}$ & $\%$ & \\
\hline 1. & Adequate Accommodation & 108 & 75 & 26 & 18.05 & 10 & 6.95 & 144(100) \\
\hline 2. & Comfortable Library Furniture & 107 & 74.30 & 32 & 22.22 & 5 & 3.48 & 144(100) \\
\hline 3. & Good Ventilation and Lighting & 107 & 74.31 & 31 & 21.52 & 6 & 4.17 & 144(100) \\
\hline
\end{tabular}

Opinion Regarding the Present Location of Library Resources

Table 9: Users Opinion about Location of Library Resources

\begin{tabular}{|c|c|c|c|c|c|c|c|}
\hline \multirow[t]{2}{*}{ PURPOSE } & \multicolumn{2}{|c|}{$\stackrel{\mathscr{E}}{二}$} & \multicolumn{2}{|c|}{$\stackrel{\circ}{Z}$} & \multicolumn{2}{|c|}{ 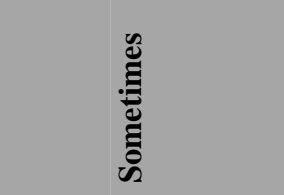 } & \multirow[t]{2}{*}{ } \\
\hline & $\begin{array}{l}\text { No. of } \\
\text { Users }\end{array}$ & $\%$ & $\begin{array}{l}\text { No. of } \\
\text { Users }\end{array}$ & $\%$ & $\begin{array}{l}\text { No. of } \\
\text { Users }\end{array}$ & $\%$ & \\
\hline General Books & 114 & 79.17 & 2 & 1.39 & 28 & 19.44 & $144(100 \%)$ \\
\hline Reference Books & 92 & 63.89 & 9 & 6.25 & 43 & 29.86 & $144(100 \%)$ \\
\hline Textbooks & 110 & 76.39 & 12 & 8.33 & 22 & 15.28 & $144(100 \%)$ \\
\hline $\begin{array}{l}\text { Display of Current } \\
\text { Periodicals }\end{array}$ & 41 & 28.47 & 39 & 27.08 & 64 & 44.45 & $144(100 \%)$ \\
\hline $\begin{array}{l}\text { Display of Popular } \\
\text { Magazines }\end{array}$ & 52 & 36.11 & 27 & 18.75 & 65 & 45.14 & $144(100 \%)$ \\
\hline $\begin{array}{l}\text { Display of } \\
\text { Newspapers }\end{array}$ & 115 & 79.86 & 8 & 5.55 & 21 & 14.59 & $144(100 \%)$ \\
\hline $\begin{array}{l}\text { Display of New } \\
\text { arrivals of books }\end{array}$ & 63 & 43.75 & 20 & 13.89 & 61 & 42.36 & $144(100 \%)$ \\
\hline
\end{tabular}

The table 9 presents the Users' opinion regarding the satisfaction of the present location of Library Resources. Majority $79.86 \%$ of User satisfaction on the display of newspapers, $79.17 \%$ on general books, $76.39 \%$ satisfied with textbooks location, $63.89 \%$ on reference books, $43.75 \%$ on display of new arrivals of books, $36.11 \%$ on display of popular magazines and only $28.47 \%$ on display of current periodicals.

\section{Opinion Regarding Purposes of Using the Internet}

It is seen from the Chart 3, that $57.64 \%$ of users using the Internet for study purposes, 22.22 of the users using the internet for sending email and chatting purposes, $9.02 \%$ of the users uses the internet for news, $8.33 \%$ of the users uses the internet for sports and Games, $2.78 \%$ of the users us on the internet for entertainment. 


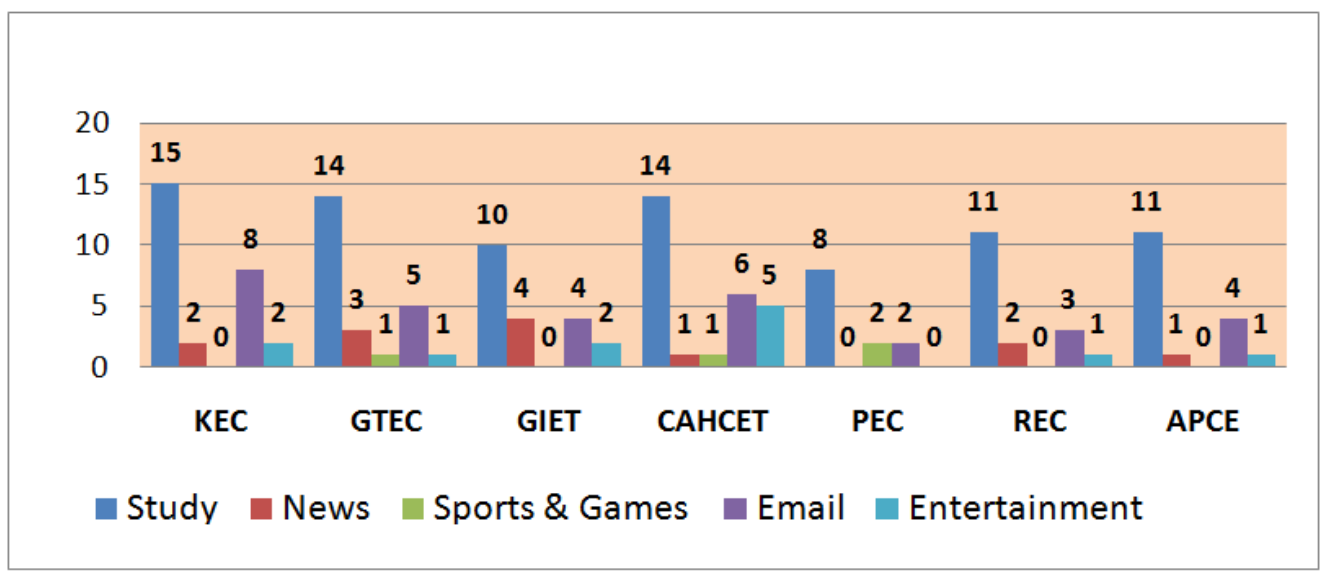

Chart 3: Users Opinion about Purpose of using the Internet

\section{Purpose of Using the Library}

The Chart 4 shows that $63.89 \%$ of the users are using the library for study, $61.81 \%$ of the users are using the Library for borrowing and return the library books, 59.03\% of the users are for preparing their assignments, 56. 95\% of the users are for the self study, $49.30 \%$ of the users are using the library for locating information in books, $45.83 \%$ of the users for reading popular magazines and Newspapers etc., $42.36 \%$ of them are using the library occasionally for preparing the notes and $35.42 \%$ users are for locating the information in periodicals.

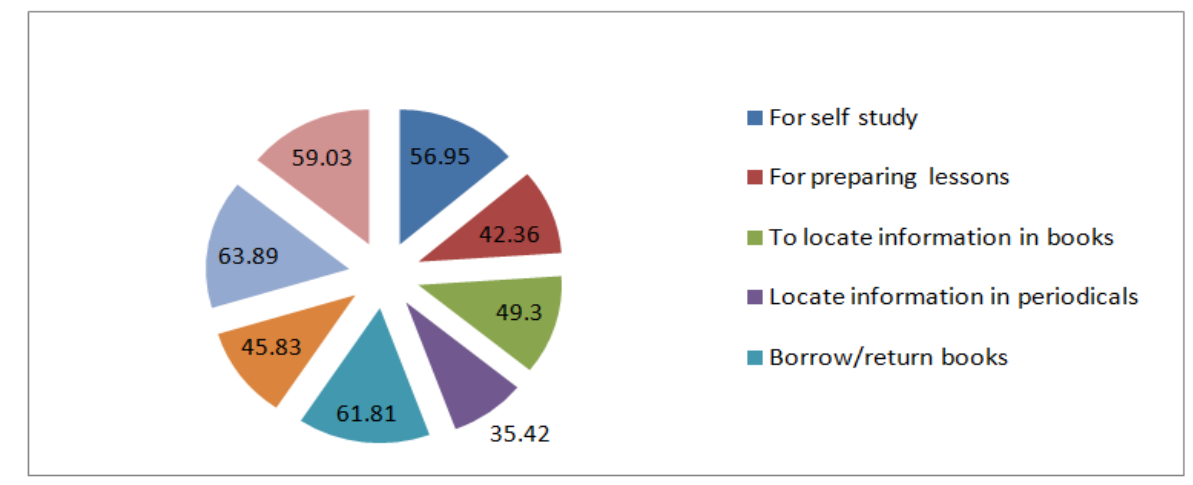

Chart 4: Users Opnion Regarding Purpose of using Library

\section{FINDINGS}

- All the users of the selected Engineering College in the Vellore District are the College Library members and they can visit the library free of cost. Most of the users (56.94\%) visited the library once a week, followed by $21.53 \%$ visit every day.

- It could be noted from table 3 that the majority of $(80.56 \%)$ users visits to the library for reading textbooks and $46.53 \%$ users visit for studying the general books, followed by $22.22 \%$ users visit for competitive Examination books.

- The majority of the respondents use the library for updating knowledge (59.03\%), while $54.17 \%$ use library for writing assignments. 
- The most of the respondents $(65.97 \%)$ used to access documents using the searching tool reference from the books.

- The majority of students (56.94\%) faced lack of time for searching the information, followed by $52.78 \%$ of them faced unavailability of information for searching.

- More than $80 \%$ of the users have expressed high adequacy of Books.

- More than $92 \%$ of them were satisfied with the Library Services.

- Most of the users (90.97\%) indicated satisfied with a library orientation program to utilize the resources effectively.

- More than $75 \%$ of Users were satisfied with the library facilities and $70 \%$ of users satisfied with arrangement of books on the shelves.

- The majority of the users (57.64\% are using the Internet for the study purposes.

- Information scattered in too many sources seem to be a major constraint faced by $56.94 \%$ respondents, while $52.78 \%$ users' sense that information materials are not updated.

\section{SUGGESTIONS}

- The most of the users desired more textbooks should be procured based on syllabus and students' demands.

- The numbers of reference books should be increased.

- The speed of the Internet should be increased.

- The library should be conducting a users' orientation program awareness Specifically on E-resources available in the library.

\section{CONCLUSIONS}

This study undertaken with the library users of Engineering Colleges in Vellore district has shown us some important aspects. The study is related to the library use, resource access, use pattern, information seeking behavior, study of the existing system, etc. A successful running of the library depends upon the Users' satisfaction-by providing required information at the right time to the users. The study identified that all engineering college libraries have been provided adequate resources and services to their users, but Users not used the available resources in an effective manner.

The library should give much more awareness to the faculty members and students, to instil them the interest to go to library and train them for the maximum use of available e-resources. These libraries shall frequently evaluate and reconstruct about the library strategy and techniques, their impact on the usages of library resources, find out and remove the problem and apply innovative methods with the users to increase usage of these resources and services.

\section{REFERENCES}

1. Chen, Ching-chen and Hernon, Peter (1982), "Information seeking: Accessing and anticipating users needs"; Neal Schuman Publisher, New York

2. Dervin, B and Nilan, M (1986). Information needs and uses. In: M.E. Williams (Ed). Annual Review of Information Science 
and Technology. New York: Knowledge Industry Publications. Vol.21.pp.3-33.

3. Wilson TD (2000). Human information behavior. Informing science: International Journal of Emerging Trans-discipline., 3(2): 49-56.

4. Majid, S. and Kassim, G. M. (2000). Information-seeking behaviour of internationallslamic university Malaysia law faculty members. Malaysian Journal of Library\& Information Science, Vol. 5, no. 2 : 1-17.

5. Kadli, Jayadev H.; Hanchinal, Veeresh B. (2015). Information-Seeking Behaviour in the Changing digital Environment: A Study of two law colleges of Mumbai. DESIDOC Journal of Library \& Information Technology.Vol.35. No.1. pp. 61-68.

6. Kadli, J., \& Kumbar, B. D. (2011). Faculty Information-Seeking Behaviour in the Changing ICT Environment: A Study of Commerce Colleges in Mumbai. Library Philosophy \& Practice, Vol.5. No. 2. pp.47-59.

7. Raza, M. Masoom; Fatima, Sarwat and Upadhyay, Ashok Kumar (2010). Information Seeking Behaviour of Researchers in Central Drug Research Institute (CDRI), Lucknow. Library Philosophy \& Practice, pp.1-10.

8. Padnzamma, S. S., Radhika, and Sunitha. (2010). Information seeking behaviour of users of PESITEM, Shimoga: a study. SRELS Journal of Information Management, Vol.47. No.6.pp.699-708. 9

9. Singh, K. P., and Satija, M. P. (2008). Information Seeking Strategies of Agricultural Scientists Working in the ICAR Institutions in India. DESIDOC Journal of Library \& Information Technology, Vol.28.No.3.pp.37-45.

10. https://en.wikipedia.org/wiki/Information needs.

11. http://digitalcommons.unl.edu/libphilprac/963. 